\title{
Liz Waldner
}

\section{Amen (On Christmas Day)}

\section{Prologue}

Rejoice all my hours-

let me, ok? (may I, mom)

I do, anyway-

a fair job.

The Play

When in these them all mine heures

I do rejoice like smelling fleurs

well then bethink me mayhaps betide

of a redhaired man whom I much done sighed.

Last nighten kneed down before candle light;

cried for them I loves and have and lost, glad of life the shining, shining on all that shineth not, said, "It's ok god if you kill me now-I liked it a lot."

A man had toyed with me and I had broke inside (if I'd a lyre the sing might song me together again);

I was the king's horse and by god as the king was a man how he did flog me for so short a ride

and breachèd sad.

So it's hey, nonny nonny-no, it is not. It's the birth, the afterbirth, the maiden, the wench, the blood on the sawdust, the warm stench. I tried, you man, you imman, twice.

Gimme flowers. 